JOURNAL OF AWARENESS

E-ISSN: 2149-6544

\title{
RAW MATERIALS AND METAL OXIDES THAT MIGHT BRING ABOUT HEALTH PROBLEMS IN THE PRODUCTION OF CERAMIC*
}

\author{
Assist. Prof. Halide OKUMUŞ \\ Çanakkale Onsekiz Mart University, Faculty of Fine Arts, Ceramics Department, \\ Canakkale/TURKEY, E-Mail: halideokumus@yahoo.com
}

Prof. Dr. Ateş ARCASOY

Marmara University, Istanbul / TURKEY

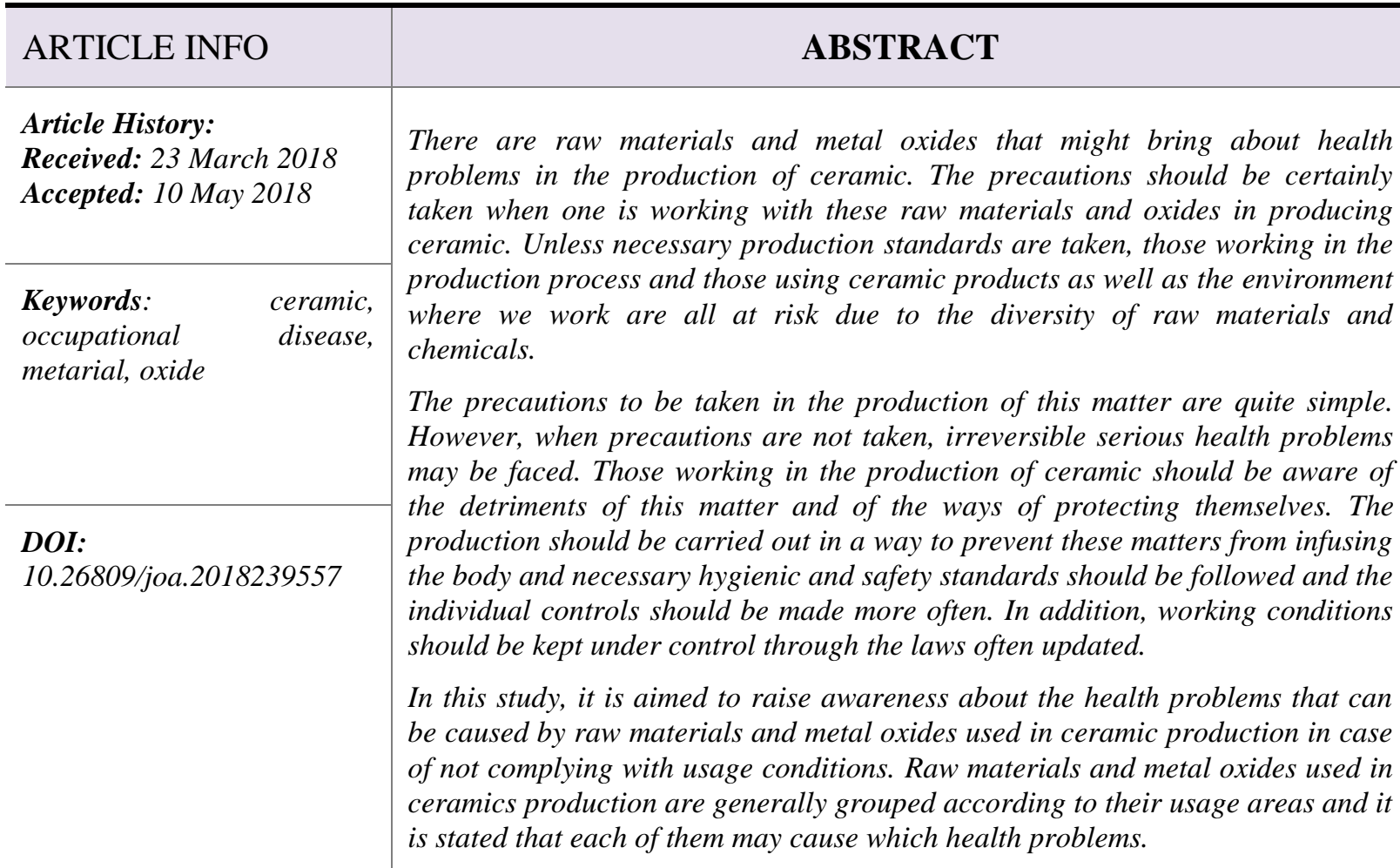

\footnotetext{
*This article has been produced from art proficiency thesis named "Precautions to be taken in terms of health in ceramic design and production". Presented on 10-12 October 2011 in Eskişehir at the "II. International Ceramics, Glass, Enamel, Glaze and Pigment Congress ".
} 


\section{INTRODUCTION}

The variety and number of chemical products used in the field of ceramic through developing technology. The lack of necessary care and attention for the fields in which these raw materials are being used and the lack of necessary precautions might cause major health problems for people working in fabrication of ceramic. It is necessary to have knowledge about the harms of raw materials, the ways of defence and applying them to be able to defend from the harms in question (Okumuş, 2006: 148).

The materials used in ceramic are divided into two groups: a) existing naturally (containing free silica: clay, feldspar, dolomite, chalk, quartz and ganister flint stone), b) chemical compounds and synthetic materials (barium carbonate, nickel oxide, lead glass). Due to the features of toxic, these oxides should be processed and used carefully. There are some materials including about \%90 free silica such as quartz, quartzite, flint stone. They have the label of harmful and people should be quite careful on using them. Chemical compounds and synthetic materials are harmful for health owing to their internal structure. These are the compounds of antimony oxide, copper carbonate, manganese dioxide, barium carbonate, kadmium and bisicilate, vanadium penta and also they have the label of harmful. More harmful and having the toxic label ones are cobalt oxide, nickel oxide, chrome oxide, lead oxide (red lead), lead carbonate (white), lead mono silicate. The reason of that cobalt does not include in this groups is that it contains a little nickel oxide and the main dangerous one is (cancerogenic) nickel oxide. Ceramic fibres being smaller than 6 micron are cancerogenic and have the label of toxic (Fraser, 1998: 121-125).

\section{RAW MATERIALS AND METAL OXIDES THAT MIGHT BRING ABOUT HEALTH PROBLEMS IN THE PRODUCTION OF CERAMIC}

\subsection{Raw Materials Used in the Compound of Ceramic Mud and Glaze}

\subsubsection{Clay -Kaoline Group Raw Materials}

Fabric is being used in compounding undercoat, glass and glaze.

Especially, at the high degree of concentration of kaoline is breathed by workers during carrying. The amount of pneumoconiosis cases seen in people who are workers exposing to kaoline is high. Kaoline shows variety as to regions and also it is dramatically mixed with other minerals. Long term, dense exposure of dust and high content of quartz causes function disorder in lungs or related to lungs with serious diseases that demolish main tissue of lungs of workers (Önal and Ökten, 2004). Pulmoner fibrozise cause not only tuberculosis but also the disease of kaoline of which symptoms are similar to silikozis when it is breathed (Karasu and Sertkaya, 2001: 27).

\subsubsection{Feldspar Group Raw Materials}

The sources of feldspar are granites, pegmatites, nepheline syenites, feldspar sand. Complex silicas composed of metal oxide construct the structure of these minerals. Alkaline which they contain is named as to oxides. The most common one is potash feldspar. The reason for that these raw materials are being used for ceramic clay is to bring $\mathrm{K}_{2} \mathrm{O}, \mathrm{Na}_{2} \mathrm{O}$, $\mathrm{CaO}$ etc. compounds to ceramic product.

They are not dangerous themselves but they might cause dangerous diseases since they lead resistance drop (Karasu and Sertkaya, 2001: 27). The compound of them contain different amounts of quartz. Therefore, it is especially important to be careful about their powders. 


\subsubsection{Quartz Group Raw Materials}

There are wide area of use in ceramic clay and glazes. In ceramic industry, mostly quartz sand and quartz rock versions of $\mathrm{SiO}_{2}$ (Arcasoy, 1983: 13,14).

Some types of sand including silica cause extreme reaction on body texture and lead a deteriorating disease. Since dust between 0.5-5 micron can move ahead alveous, it can cause pneumoconiosis. As dense and period of breathing of dust increases, the risk of becoming ill also increases. Mostly 15-20 years are required for occurring of pneumoconiosis for people who expose to low dense of dust. In the basis and processing of the disease, there is the role of enzymes which occur as a result of breaking up cells absorbing silica crystals prevent loss of blood by thrombosing of blood melt and digest protein. When silica is breathed, it might lead two main histological reactions (Şakar and others, 2005: 148-155) as silicotic nodule and silicoproteinozis, silicosis, pneumonitis and asthma (Canduran, 2006: 124).

\subsubsection{Raw Materials Including Carbonate}

Calc $\left(\mathrm{CaCO}_{3}\right)$ is the raw material containing carbonate such as magnesite, dolomite $\left(\mathrm{CaCO}_{3} \cdot \mathrm{MgCO}_{3}\right)$.

The calcite dust might cause irritation in upper respiratory tract in the condition of exposing continually and with great amount of it (URL-4, 2008).

Carbonates which take place in raw materials spoil at different temperatures as to the type of metal oxide which they depend on turn into metal oxide and carbon dioxide $\left(\mathrm{CO}_{2}\right)$ (Güner, 1987: 84). Carbon dioxide/monoxide causes pulse, increasing blood pleasure and headache, dizziness because it drops the amount of oxygen in blood by combining haemoglobin. Carbon monoxide is a kind of gas which is colourless, scentless and does not have an effect of irritating. Since the first symptoms of poisoning are feeling tired, weakness, the condition of coma bursts onto the scene. Long term poisoning of carbon monoxide might cause heart diseases (Canduran, 2006: 124). The most serious danger is poisoning of carbon monoxide in heater (Ilsley, 1999: 131-134). Calsite used in compounding fabric and glaze brings about gallbladder stone (URL-3, 2007).

\subsubsection{Other Raw Materials}

Wollastonite $\left(\mathrm{CaSiO}_{3}\right)$, talc-soap stone $\left(3 \mathrm{MgO} .4 \mathrm{SiO}_{2} \mathrm{H}_{2} \mathrm{O}\right)$, pyrophylite $\mathrm{H}_{2} \mathrm{Al}_{2}\left(\mathrm{SiO}_{3}\right)_{4}$ boron and boron minerals belong to the concept of other raw materials.

The structure of talc with fibre is because of asbestos minerals (URL-9, 2007). Pulmonary fibrosis (URL-3, 2007), talcosilicosis (Önal and Ökten, 2004) are seen depended on talc and they might cause irritation in eyes and respiration system (URL-4, 2008).

\subsection{Oxides Used in Compound of Ceramic Glaze}

\subsubsection{Aluminum Oxide $\left(\mathrm{Al}_{2} \mathrm{O}_{3}\right)$}

It is used in the structure of glaze and oxide ceramic. Kaoline, clay and feldspar generally benefit from $\mathrm{Al}_{2} \mathrm{O}_{3}$.

They have an important role in producion of ceramic and frit's dye. It colours the dye to make it resistant to heat and oxide is tied $\mathrm{Al}_{2} \mathrm{O}_{3}$. (URL-8, 2007).

It causes the disease of aluminosis, difficulty in breathing and chronic bronchitis (Canduran, 2006: 124). 


\subsubsection{Barium Oxide $(\mathrm{BaO})$}

It is acquired as barium sulfate (Barite) and sometimes barium carbonate (Witherite). It leads benign pneumoconiosis for workers serving in these jobs or on mining mineral ores and interstitial involvement appearing in lungs is called barytosis. Among workers who expose to barium salt there seems to the utmost radio-dense thin nodules in lungs of in onetwo years depend on the weight of high atom of barium. There are histological air spaces in lungs and there are barium partides in interstitial tissue (Önal and Ökten, 2004).

The use of barium compounds is restricted to be used due to the fact that they have the feature of toxic (Kartal, 1998: 21). Generally, it is dangerous for open wound because BaO taken from barium carbonate is poisonous (Arcasoy, 1983: 13,14).

Barium carbonate is the most dangerous derivation of barium. The absorption of even one gram of barium carbonate by the body ends up death. The form of fusible chloride accumulates in stomach and causes an increase blood pressure as a result it causes internal bleeding. It might enter the body by means of skin (Canduran, 2006: 124). It is harmful that it touches the skin and it is taken by oral ways and respiration. It irritates the eyes (Karasu and Sertkaya, 2001: 27). When barite is breathed long time and with a high amount, it endangers respiration system and lungs, it might bring about irritation (URL-4, 2008).

\subsubsection{Boric Oxide $\left(\mathrm{B}_{2} \mathrm{O}_{3}\right)$}

It is used in production of glaze. The most important compounds are pandermite, cholemanite, ulexide, borax, boric aside (URL-8, 2007).

To make involvement of boric to compound of glaze safe, it should be shaped as glass or it should be used in the form of cholemanite. It should be avoided to take it by the means of skin or oral ways (Karasu and Sertkaya, 2001: 27)' (Canduran, 2006: 124). When poisoning as vomiting, diarrhea, trembling are observed there occur skin eruption and disorders in liver, kidney, and central nervous system (URL-1, 2000). It is thought that boric causes infertile for women and men, growth deficiency for baby during pregnancy period and also some kinds of abnormalities (URL-5, 2007).

Impotence, sexual anorexia, shortening number of sperm and degeneration of its morphology are observed in men. Moreover, it leads miscarriage in women and the increase of risk in the number of death birth (URL-6, 2007).

\subsubsection{Fluorine (F)}

The compound of fluorine used is used as calcium fluorine, aluminium fluorine, sodium hexafluorosilicate and cryolite. Calcium fluorine exists as fluorite and fluorspar. It is so active and melting and also it shows the effect of increasing fluidity in glaze. Since fluorine ion is volatile, it should be used in glaze and glass carefully (Bozdoğan: 23). Fluoride source of which is the calcium fluorine (fluorine spar), and used in compounding structure, in cauterizing ceramic and glass products and in preparing ceramic dyes is dangerous to breathe or to be taken orally. It irritates skin and eyes. Aspiration is necessary in the places where gas outlet occurs. The touch the skin should be avoided (Karasu and Sertkaya, 2001: 27). There are special rules about using and storing hydrofluoric acid which is very dangerous material (Fraser, 2005: 171-180).

The continual quality of sodium silica fluoride obtained as by-product is being used in the process, in producing glass in the condition necessary precautions against environmental pollution, especially obtaining glaze which cooks at low heat with titan. Sodium silica fluoride is poisonous (URL-8, 2007). 


\subsubsection{Calcium Oxide ( $\mathrm{CaO})$}

Calcite which is calcium compounds used as calcium carbonate $\left(\mathrm{CaCO}_{3}\right)$ includes limestone, marble, chalk carbonate. Carbonates dissolve at different heat according to the type of metal oxides that it is based on turn into metal oxides and $\mathrm{CO}_{2}$.[7] One of the biggest dangers is carbon monoxide poisoning which comes off ceramic kilns.

Calcite used for compounding structure and glazes brings about existing of gallstones (URL-3, 2007).

\subsubsection{Lead oxide ( $\mathrm{PbO})$}

Compounds used are red lead $\mathrm{Pb}_{3} \mathrm{O}_{4}$ (red), lead oxide $\mathrm{PbO}$ (yellow), lead carbonate, $\mathrm{PbCO}_{3}$ (white) (URL-8, 2007). The steam of lead that revealed during melting has got a fatal effect.

Lead that was a dispensable raw material of low heat glaze a few years ago is getting to lose its value because it is poisonous and it can not be abolished by the nature. Glaze which contains lead oxide is unfavourable in using for ceramic products containing food as it resolves in hot water and diluted acetic acid even it is glassed (Bozdoğan: 23).

Whereas lead is a poisonous material, it is known to include minerals providing lead such as silver, bismuth, manganese, cadmium, arsenic, antimony, spelter, iron, cobalt, and nickel at high or low levels. This material which has low melting and evaporation heat should be strictly prevented from transferring to atmosphere during maturation of glaze and producing of glass.

It is dangerous that all the compounds of lead are taken by breathing, orally and touching skin. Addition of lead to glaze in a safer way is possible with using lead bisicilate glass. However, its dust is still dangerous (Karasu and Sertkaya, 2001: 27). It is dangerous because it can not discarded easily and it accumulates in bones and soft tissue. $\% 40$ of lead taken by means of breathing and \%10-15 of lead taken via digestive system are absorbed by the body. Lead affects mostly neural system. The taste of metallic, stomach-ache, lack of appetite and costiveness are important symptoms of lead poisoning. Cerebral oedema and disorders in kidney are the results of lead poisoning (Canduran, 2006: 124).

Related to fertility of people who are working in art and ceramic workshop, men face to impotence, sexual anorexia, the loss in the number and quality of sperm, the disorders in morphology, infertility and the increase in possibility of miscarriage and dead births. Among women, menstrual irregularity, the increase in the risk of miscarriage and death births and infertility can be observed (URL-5, 2007).

Lead first enters into red blood cells, then omits the iron placed in the cell and replaces it. Anaemia occurs as a result of loss of iron in the body. When the lead is absorbed too much, it accumulates in spleen, liver, kidney and also mostly in skeleton. Lead exists around teeth and also in bowels due to its tendency to sulphur. Mostly chronic poisoning is observed. Poisoning arises from breathing or touching the skin. In early stage, loss of appetite, loss of weight, headache, anaemia, a taste of iron, bloodlessness, complaints in stomach and dark bluish lines in gingival. Moreover, in further stages, restlessness, feeling angry, repetitive vomiting, pain in joint, paralysis of hands and feeling disorders are observed. In the furthest stage, high blood pressure, continual vomiting, cerebral oedema, disorders in nervous system resulted from spasm in brain vessels are observed (URL-7, 2007) 


\subsubsection{Lithium Oxide $\left(\mathrm{Li}_{2} \mathrm{O}\right)$}

$\mathrm{Li}_{2} \mathrm{O}$ is quite strong melting materials in glazes. It is used in ceramic glaze and mud. The artificial lithium compounds used in ceramic industry are lithium alimunate, lithium carbonate, lithium silicates, lithium titanate and lithium-zircon silicates. There are compounds as $\mathrm{Li}_{2} \mathrm{O}$ petalite $\left(\mathrm{Li}_{2} \mathrm{O} \cdot \mathrm{Al}_{2} \mathrm{O}_{3} \cdot \mathrm{SiO}_{2}\right)$ and spodumene $\left(\mathrm{Li}_{2} \mathrm{O} \cdot \mathrm{Al}_{2} \mathrm{O}_{3} \cdot 4 \mathrm{SiO}_{2}\right)$ (Arcasoy, 1983: $13,14)$.

$\mathrm{Li}_{2} \mathrm{O}$ causes scars in bone marrow and its symptoms are quiet similar to cancer's (Canduran, 2006: 124).

\subsubsection{Silicon Dioxide (SiO2)}

It is only common oxide in all glazes. $\mathrm{SiO}_{2}$ can be taken from clay, kaoline, feldspar and mostly quartz and inserted to glazes.

Quartz used in compounding structure and glaze might cause pneumonitis (Karasu and Sertkaya, 2001: 27), silicosis and asthma (Canduran, 2006: 124). As the quite fine dust is breathed, the diseases of lungs and at the last stage tuberclosis appear. The actual dangerous one is silica dust. The partides which are smaller than $5 \mu$ can easily pass defence system and easily damages lungs. The more massive partides are prevented by the nose (Fraser, 1998: 121-125).

\subsubsection{Thorium Oxide $\left(\mathrm{ThO}_{2}\right)$}

Oxide consists in the form of ceramic. Thorium oxide is used as the form of calcine in ceramic. Due to its having radio active, some precautions should be taken during using it (Arcasoy, 1983: 13,14). Thorium is cancerinogenic. It causes tumour in livers and kidneys and scars in lungs. It might hold on bones, lungs and other organs of the body for year (URL2, 2008).

\subsection{The Oxides Used in Colouring of Ceramic Muds and Glazes}

\subsubsection{Antimony Oxide $\left(\mathrm{Sb}_{2} \mathrm{O}_{3}, \mathrm{Sb}_{2} \mathrm{O}_{5}\right)$}

It works as colouring in glazes and as opacifing in low heat glazes. However, it does not perform this duty on its own. It gives the colour of yellow due to having lead oxide and iron oxide. Basic naples yellow $\left(\mathrm{Pb}_{3}\left(\mathrm{SbO}_{4}\right)_{2}\right)$ is an antimony dye and it is also used as the source of antimony by ceramicists. It dissolves a little in the water. Its effect of toxic is really heavy (Sümer, 2002: 4). The sources are antimony trioxide and antimonypentaoxide. It is harmful to be taken by breathing, orally and touching skin. It irritates the skin (Karasu and Sertkaya, 2001: 27)

\subsubsection{Arsenic Oxide $\left(\mathrm{As}_{2} \mathrm{O}_{3}, \mathrm{As}_{2} \mathrm{O}_{5}\right)$}

It is rarely used in glazes. Its compounds is quiet harmful Arsenic oxide or arsenic acid is added to all silica formulas (Sümer, 2002: 4). It is easily evaporates through glazes. It is forbidden to work with arsenic compounded glazes because of its poisonous structure (Arcasoy, 1983: 13,14).

Arsenic leads chromosomal abnormalities and infertility in men. The possibility of miscarriage of women increases. It causes growth deficiency in fetus, neural system and skeletal abnormalities (URL-5, 2007).

It is the reason for irritation in arsenic upper respiratory and skin and bowels. \%50 of cases shows that there are some symptoms belong to upper respiratory irritation and lesions that compose pustules on skin. Individuals who expose to it, small, dense and radiological 
widespread nodules are found in both two lungs. It is indicated that there is a relationship between antimony trioxide and lung cancer in studies with animals and epistemologically (Önal and Ökten, 2004). Arsenic accumulates in hair and can be placed for months. The control of poisoning can be done by hair. Although all of the as compounds are poisoning, the ones that have the value of +3 are more poisoning. Even $100 \mathrm{mg}$ of as is fatal for people. Weakness, scars on skin, nervous breakdown and poisoning are observed (Doğan, 2002: 3236).

\subsubsection{Copper Oxide ( $\left.\mathrm{CuO}, \mathrm{Cu}_{2} \mathrm{O}\right)$}

Copper oxide is the oldest colouring oxide among used ones. It exists mostly with limonite (URL-8, 2007).

It is not true that copper oxide is used with lead glazes. Lead oxide is poisoning. The food or drink which is lined with copper oxide and vitrified with lead glaze is going to contact with glaze, it is going to absorb the glaze and to cause poisoning. Copper sulphate is used as the form of soluble copper however it is quiet poisonous (Çobanl1, 1996: 42).

It is dangerous to be taken by orally and breathing. It irritates the skin and eyes. All of the copper compounds accelerate the lead's leaving from the glaze (Karasu and Sertkaya, 2001: 27).

The copper chronically taken at high amount might cause second degree burn in brain and lungs. The salt of copper and its steam not only irritates eyes and mucous membrane but it also irritates respiratory passages when it is breathed (Canduran, 2006: 124).

\subsubsection{Beryllium Oxide}

The source of it is berylliym mineral. Oxide exists in the form of ceramic. As $\mathrm{BeO}$ is very poisonous, it is necessary to work carefully during producing oxide and process of using it. Pure $\mathrm{BeO}$ reaches a developed structure only at very high heat (Arcasoy, 1983: 13,14).

Exposing to beryllium appears when mineral leaves from the ore of beryl and bertandite and when it processes the beryllium metal compounds and the products of ceramic. Late hypersensitive reaction causes the disease of systematic granulomatous reaction (beryllosis) which is known as chronic beryllium and skin disease (Önal and Ökten, 2004).

Beryllium oxide is used as ceramic material in nuclear reactors. It is also used in compounding structure. It is harmful to take it y breathing and orally. The dust of beryllium and its compounds has the affect of poison (URL-9, 2007).

\subsubsection{Iron Oxide $\left(\mathrm{FeO}, \mathrm{Fe}_{2} \mathrm{O}_{3}, \mathrm{Fe}_{3} \mathrm{O}_{4}\right)$}

The sources of iron oxide are iron and its compounds. Different colours are obtained at the different heating atmosphere with iron oxide.

The most common and well known of good-tempered pneumoconiosis is siderosis which is related to siderosis. The occupational exposure of iron appears during obtaining or procession of ironstone. The workers who expose to metallic iron or iron oxide also expose to other dusts (quartz, asbestos, clistobalite). In this way, mixed siderosis dust complicates with pneumoconiosis or asbestos and it results in disease. Cases with siderosis do not give symptoms whereas there are some complaints such as coughing and difficulty in breathing in cases with silicosideros. Smoking accelerates harm in lungs or disorders in the functions of lungs. Pure iron brings about tendency to tuberculosis (Önal and Ökten, 2004). If it is taken more than $0,5 \mathrm{mg}$, it has got a poisonous effect. It might cause ulcer in stomach and in further cases it might cause bleeding. If it is breathed too much, it leads the cancer of lungs. 


\subsubsection{Kadmium Oxide $(\mathrm{Cd})$}

The source of kadmium oxide is sulphur and kadmium sulfoselenide. It is used to obtain the colours of yellow, orange and red. It irritates eyes (Karasu and Sertkaya, 2001: 27). It affects the system of enzymes. It harms respiratory system, stomach and bowels and it is known that it causes cancer. Even a small amount of kadmium oxide taken through respiratory system or digestive system might lead serious poisoning. Therefore, pure kadmium oxide must be used very carefully. There might be weakness such as feeling tired, lack of the smelling sense due to long term exposure of cadmium (Canduran, 2006: 124).

When impotence, sexual anxiety, decreasing in the number of sperm and abnormalities in its morphology are observed among men, women come across miscarriage, menstrual irregularity and the risk in the birth of low weight babies (URL-6, 2007).

Acute and chronic poisoning is also observed because of kadmium. The most important effect of chronic kadmium poisoning is especially the cancer of lung and prostate. The excess amount of taking kadmium causes the effect of ruination in kidneys. Osteolysis and some diseases related to this are observed due to kadmium poisoning. On the other hand, anaemia and loss of teeth are other important affects of cadmium (URL-10, 2007). It is as dangerous as kadmium mercury and even the metal and its oxide that reach lungs are cancerogenic (Doğan, 2002: 32-36).

\subsubsection{Tin Dioxide $\left(\mathrm{SnO}_{2}\right)$}

$\mathrm{SnO}_{2}$ which is the most famous material in the field of hiding power in ceramic technology also constructs the basement of most ceramic dyes (URL-8, 2007).

Pneumoconiosis (Stannosis) which is the result of breathing tin is observed especially among people who expose to smoke of tin oxide during processing mineral ore (Önal and Ökten, 2004). It brings about coughing, difficulty in breathing and at the same time it lead white pigments (Canduran, 2006: 124)

\subsubsection{Cobalt Oxide $\left(\mathrm{CoO}, \mathrm{Co}_{2} \mathrm{O}_{3}, \mathrm{Co}_{3} \mathrm{O}_{4}\right)$}

The sources of cobalt oxide are carbonate, cobalt silicate and cobalt aluminate. It is used for getting the colours of black and blue (URL-8, 2007).

It reached the body by means of skin and it harms liver. The types such as cobalt carbonate and oxide irritate skin and eyes. It gives harm lungs if it is breathed. (Canduran, 2006: 124). Some symptoms such as dry cough and irritation in upper respiratory tract are observed among people who expose to cobalt at the higher level of concentration than thresold limit value especially on sintering at the end of the day. These symptoms disappear a few days later they stop working. Clinical progress in asthma depending on cobalt is quite good. However symptoms might be chronically in some cases in which exposure is keeping on (Önal and Ökten, 2004).

\subsubsection{Chrome Oxide $\left(\mathrm{Cr}_{2} \mathrm{O}_{3}\right)$}

The source of chrome oxide is chromate. It is one of the most decisive oxides which have got fine-grain. The most important black and brown ceramic dyes used in coating ceramic are iron chromate spinels obtained by means of calcining iron oxide and chrome oxide at above $1000^{\circ} \mathrm{C}$ (URL-8, 2007).

Chrome compounds especially the ones which are six-valued as chromates causing skin cancer are harmful. It must be avoided to take it by touching and orally (Karasu and Sertkaya, 2001: 27). Chrome that is the factor of lung cancer might cause ulcer (Canduran, 
2006: 124). Chrome compounds being six-valued ones harms DNA and brings about gene mutation.

It is found that people who expose to chrome as a result of breathing and touching the skin come across health problems. Taking Cr6+ to body via the air causes running rose, nose bleeding, itching and puncturing in upper respiratory tract and also asthma crisis are observed among people who are allergenic chrome. Taking $\mathrm{Cr} 3+$ by means of air does not affect negatively as much as Cr6+ (URL-10, 2007).

\subsubsection{Manganese Dioxide $\left(\mathrm{MnO}_{2}\right)$}

Manganese is used in glazes to get black, brown and purple colours (URL-8, 2007).

It is so poisonous. It is dangerous to take it by means of breathing and orally. It irritates skin and eyes (Karasu and Sertkaya, 2001: 27). It harms neural system. The damages in lungs are observed. Its harms appear after a long time as 10-20 years. Mangan poisoning might cause the disease of Parkinson. The long term exposure might harms the brains and as a result it causes deaths (Canduran, 2006: 124). It leads impotence, sexual anorexia, infertility related to hormonal irregularity among men and neural system disorders in developing fetus (URL-6, 2007), (URL-8, 2007).

\subsubsection{Nickel Oxide ( $\left.\mathrm{NiO}, \mathrm{Ni}_{2} \mathrm{O}_{3}\right)$}

Nickel oxide exists as sulphur, silicas and arsenide along with mostly iron in the nature. It is an effective colouring. It is used to obtain various colours and tones such as blue, grey and green (URL-8, 2007).

It is dangerous to take it by breathing and orally. It causes the cancer of lungs and nasal sinus (URL-3, 2007), and dermatisis are observed as a result of touching it (Karasu and Sertkaya, 2001: 27). Moreover, malignant tumour with cancer in lung squmous are observed among workers. Ni leads allergy in sensitive skins (Doğan, 2002: 32-36) and Ni taken by breathing is cancerogenic.

\subsubsection{Selenium Compounds (Se-)}

Apart from selenium as element, selenium sodyum selenite, barium selenite, zinc selenite, kadmium selenite and selenium sulphite compounds are used in glazes (Arcasoy, 1983: 13,14).

It is dangerous to take it by breathing and orally. The smoke of selenium released as a result of deformation is poisonous.[9] It might cause deaths when it is taken with high amounts. It has also harmful effects to liver when it is exposed to it (Canduran, 2006: 124).

\subsubsection{Titanium Dioxide $\left(\mathrm{TiO}, \mathrm{TiO}_{2}, \mathrm{TiO}_{3}, \mathrm{Ti}_{2} \mathrm{O}_{3}\right)$}

It exists as ilmenite (iron titanate) and rutile (titanium dioxide).

It is possible to expose titanium dusts in the process of obtaining, using or storing mineral ore. The dust which enters the body by breathing can accumulates in some parts. The dust which exists in air excessively is irritating. It has an effect to deteriorate respiratory tract diseases. Titanium oxide is held in lungs. Little evidence in lungs shows that it also deteriorates the reaction of lungs (URL-2, 2008).

\subsubsection{Uranium Oxide ( $\left.\mathrm{UO}_{2}, \mathrm{UO}_{3}\right)$}

It is used in compounding glazes. All of the uranium compounds are poisonous and it must be taken into consideration on using it. At the same time when uranium excesses the certain amounts on releasing radiation, it turns into a harmful material for health (Arcasoy, 
1983: 13,14).

\subsubsection{Vanadine Oxide $\left(\mathrm{V}_{2} \mathrm{O}_{3}, \mathrm{~V}_{2} \mathrm{O}_{5}\right)$}

It works as colour carrier in glazes.[26] $\mathrm{V}_{2} \mathrm{O}_{5}$ is used to gain the colour of blue. It is dangerous that it is taken by breathing and orally. It irritates skin and eyes (Karasu and Sertkaya, 2001: 27).

\subsubsection{Zircone Dioxide $\left(\mathrm{ZrO}_{2}\right)$}

Zircone oxide which is used to make glazes covering is mostly being used as zircone silicas $\left(\mathrm{ZrSiO}_{4}\right)$ and the glazed used mostly are glazes with zircone. Zircone exists in the glazes of pure health materials as oxide and at the same time it exist in the structure of oxide ceramic (Arcasoy, 1983: 13,14). Zircone has generally a radioactive feature due to its including torium contents (URL-8, 2007).

Zircon oxide used in production of ceramic is a heavy metal. It is thought that it is not active chemically in the tissue of lungs and its feature of involving chemical reaction by processing can be abolished. Only one case of pulmonary fibrosis is known about it usage. It is acknowledged that among some people and organs but especially in lungs the disease of sarcoidosis which is observed when coarse and infected swellings appear in tissues or granulomatous interstitial lung disease which is similar to pneumonitis appearing with the reaction of acute immunization. It is also observed that zircon oxide causes similarly granulomatous hyper sensitive reaction in the skin among people and some studies with animals (Önal and Ökten, 2004).

\section{CONCLUSION AND SUGGESTION}

There are a number of raw materials and metal oxide which are found dangerous even they are exposed for a short time. It is important to know how harmful materials affect health of people in terms of having the knowledge of protection ways to be taken.

It is possible to avoid effects of harmful materials with some precautions such as appropriate air circulation conditions in big factories in the sector of ceramic, using mask and using harmful raw materials in glaze derivation. However people who work smaller ceramic workshops and art workshops in which working conditions are appropriate, which lack of necessary care and knowledge are closely prone to the effects of harmful chemical materials.

That materials especially used in preparing glaze and structure are prepared in a dry way, dry retouching pieces of ceramic and different gases released from the heaters cause that these materials mix to the air breathed in working environment. The materials taken by breathing harms respiratory tracts much more in the working conditions in which air conditioning is not good and masks are not used (Canduran, 2006: 124).

People who are working in production of ceramic should know the harms of raw materials and metal oxides they use, the protection ways. Production should be done as these materials do not reach human bodies, necessary hygiene and security standards should be followed and personal controls should be increased.

Legal regulations should be frequently updated, related standards, laws and regulations should be followed carefully, clean and the newest technologies should also followed without interrupt and in advance to more healthy people, a safer working environment, a cleaner nature, a more qualified product and life (Okumuş, 2008: 157). 


\section{REFERENCES}

ARCASOY, A., (1983), Seramik Teknolojisi, İst., M.Ü. G.S.F. Seramik ASD Yay., No:2, 13,14.

BOZDOĞAN, İ., "Sır Hammaddeleri ve Sır Kompozisyonu Üzerindeki Etkileri”, Seramik Sirları Semineri Bildiriler Kitabı, 2. Bask1, Türk Seramik Derneği Yayınları, No:7, 23.

CANDURAN, K., (2006), "Seramikte Toksik Maddeler", Seramik Türkiye, Seramik Federasyonu Dergisi, No:14, 124.

ÇOBANLI, Z., (1996), Seramik Astarları, Eskişehir, AÜ Yay. No 919, GS Yay. No 15, 42.

DOĞAN, M., (2002), "Sağlıklı Yaşamın Kimyası”, Popüler Bilim Dergisi, 32-36.

FRASER, H., (2005), Ceramic Faults and Their Remedies, Second Edition, A\&C Black. Publisher Ltd. London, 171-180.

FRASER, H., (1998) Glazes for the Craft Potter A\&C Black, London, The American Ceramic Society, 121-125.

GÜNER, Y., (1987), Seramik, İstanbul, Gençlik Kitabevi A.Ş, 84.

ILSLEY, P., (1999), Macro - Crystalline Glazes The Challange of Chrystals, The Crowood Pres, Marlborough: 131-134.

KARASU, B. and SERTKAYA, A. (2001), "Seramik Sektöründe Karşılaşılan Belli Başlı Sağlık Problemleri, Nedenleri ve Alınması Gereken Tedbirler (2)", Seramik Sanat, Bilim ve Teknoloji, Say1:14, 27.

KARTAL, A., (1998), Sır ve Sırlama Tekniği, Çizgi Matbacılık Ltd. Şti., Mart, 21.

OKUMUŞ, H., (2009), "Seramik Üretiminde Karşılaşılan Sağlık Sorunları ve Alınması Gereken Önlemler", SERES 11. 1.Uluslararası Seramik, Cam, Emaye, Sir ve Boya Kongresi Bildiriler Kitabı, 377-387.

OKUMUŞ, H., (2008), Seramik Tasarım ve Üretiminde Sağlık Açısından Alınması Gereken Önlemler, Sanatta Yeterlik Tezi, Marmara Üniversitesi Güzel Sanatlar Enstitüsü, 157.

OKUMUŞ, H., ALDIRMAZ AĞARTAN, C. and YILMAZ, S. (2008). "Sağlik Açısından Geleneksel Çanakkale Seramikleri”, Çanakkale Merkezi değerleri Sempozyumu Bildiriler Kitabı, 795.

OKUMUŞ, H., (2006), "Seramik Üretiminde Sağlık Açısından Dikkat Edilmesi Gereken Hammadde ve Metal Oksitler”, III. Ulusal Analitik Kimya Kongresi, Bildiri Özetleri Kitabı: 148.

ÖNAL, M. and ÖKTEN F., (2004), “İnorganik Tozlara Bağlı Akciğer Hastalıkları”, Difüz Parankimal Akciğer Hastalıkları, 1. Bask1, 99.

SÜMER, G., (2002), Seramik Sirları, Eskişehir, Ak Ofset-Matbacılar Sitesi, 4.

ŞAKAR, A., KAYA, E., ÇELIK, P., GENCER, N., TEMEL, O., YAMAN, N., SEPIT, L., YILDIRIM, Ç. A., DAĞYILDIZI, L., COŞKUN, E., DİNÇ, G., YORGANCIOĞLU, A. ve ÇIMRIN A. H., (2005), Seramik Fabrikası İșçilerinde Silikozis" Tüberküloz ve Toraks Dergisi, Cilt: 53 Say1:2, 148-155.

(URL-1) http://www.bigadic.gov.tr/semboller/bor1.asp Ankara, Mayıs 2000.

(URL-2) http://ceramic-materials.com/cermat/education/299.html (erişim tarihi 2.04.2008)

(URL-3) http://www.dicle.edu.tr/fakulte/tip/dergi/yayin/15(.)InsanSagligina.doc (erişim tarihi 10 Ekim 2007).

(URL-4) http://www.ercminerals.com/tr/forms.html (09 Eylül 2008).

(URL-5) http://www.fertijin.com.tr/?kbase=112\&tab=\&lang=tur (erişim tarihi 9 Ekim 2007). 
OKUMUSS \& ARCASOY / Raw Materials And Metal Oxides That Might Bring About Health Problems in the Production of Ceramic

(URL-6) http://www.kadinhastaliklarivedogum.com/infertilite/is.asp (erişim tarihi 9Ekim 2007).

(URL-7)

http://www.kimyaokulu.com/merak\%20ediyorsaniz/html/is_guvenligi_yonunden_kursun.htm (erişim tarihi 06.9.2007).

(URL-8) http://www.madencilik.net/sir.asp (erişim tarihi 06.12.2007).

(URL-9) http://www.migem.gov.tr/links/kaynakca/sozluk/sozluk-t.htm (erişim tarihi 9 Ekim 2007).

(URL-10)

http://66.102.9.104/search?q=cache:CdxDxXcIUnMJ:www.metalurji.org.tr/dergi/dergi 136/d136_4753.pdf+OSHA+seramik\&hl=tr\&ct=clnk\&cd=19\&gl=tr\&lr=lang_tr (erişim tarihi 9 Ekim 2007). 